\title{
FACTORS ASSOCIATED TO ADHERENCE TO DIFFERENT TREATMENT SCHEMES WITH MEGLUMINE ANTIMONIATE IN A CLINICAL TRIAL FOR CUTANEOUS LEISHMANIASIS
}

\begin{abstract}
Madelon Novato RIBEIRO(1), Maria Inês Fernandes PIMENTEL(1), Armando de Oliveira SCHUBACH(1), Raquel de Vasconcellos Carvalhães de OLIVEIRA(1), José Liporage TEIXEIRA(1), Madson Pedro da Silva LEITE, Monique FONSECA(1), Ginelza Peres Lima dos SANTOS(1), Mariza Matos SALGUEIRO(1), Erica de Camargo Ferreira e VASCONCELLOS(1), Marcelo Rosandiski LYRA(1), Mauricio Naoto SAHEKI(1) \& Claudia Maria VALETE-ROSALINO(1,2)
\end{abstract}

\begin{abstract}
SUMMARY
The favorable outcome of the treatment of a disease is influenced by the adherence to therapy. Our objective was to assess factors associated with adherence to treatment of patients included in a clinical trial of equivalence between the standard and alternative treatment schemes with meglumine antimoniate (MA) in the treatment of cutaneous leishmaniasis (CL), in the state of Rio de Janeiro. Between 2008 and 2011, 57 patients with CL were interviewed using a questionnaire to collect socioeconomic data. The following methods were used for adherence monitoring: counting of vial surplus, monitoring card, Morisky test and modified Morisky test (without the question regarding the schedule); we observed $82.1 \%$ (vial return), $86.0 \%$ (monitoring card), 66.7\% (Morisky test) and $86.0 \%$ (modified Morisky test) adherence. There was a strong correlation between the method of vial counting and the monitoring card and modified Morisky test. A significant association was observed between greater adherence to treatment and low dose of MA, as well as with a lower number of people sleeping in the same room. We recommend the use of the modified Morisky test to assess adherence to treatment of CL with MA, because it is a simple method and with a good performance, when compared to other methods.
\end{abstract}

KEYWORDS: Cutaneous leishmaniasis; Pentavalent antimonials; Adherence; Therapy; Treatment.

\section{INTRODUCTION}

Cutaneous Leishmaniasis (CL) is a disease caused by a protozoan of the Leishmania genus and transmitted by the bites of female Phlebotomus (Dipteran, Psychodidae, Phlebotominae). In the state of Rio de Janeiro, Brazil, CL is caused mainly by L. (Viannia) braziliensi S $^{1,28}$.

Pentavalent antimonials have been used for decades and are still the first drug of choice in the treatment of leishmaniasis, despite its known toxicity, difficult handling and not fully understood mechanism of action $^{9,10}$.

Meglumine antimoniate (MA) is supplied in $5 \mathrm{~mL}$ vials containing $1.5 \mathrm{~g} \mathrm{~N}$-methylglucamine, equivalent to $405 \mathrm{mg}$ of pentavalent antimony $\left(\mathrm{Sb}^{5+}\right)^{34}$. It can be administered parentally (IM or IV). The therapeutic schemes may vary in duration, total dose and daily dose. Poor therapeutic response has been described ${ }^{29}$.

In Brazil, the Ministry of Health ${ }^{18}$ recommends a dose of $10-20 \mathrm{mg}$ $\mathrm{Sb}^{5+} / \mathrm{kg} /$ day, over 20 days, taking into consideration a maximum limit of three vials per day, to treat CL patients with MA.

Clinical studies in Rio de Janeiro, with long-term patient monitoring, have suggested that both, the use of regular schemes with low doses (5 mg Sb ${ }^{5+} / \mathrm{kg} /$ day) administered systemically and the intralesional therapy with $\mathrm{MA}^{18,22,30,31}$, can be effective schemes, achieving cure rates similar to those obtained with higher doses, although with lower toxicity, greater ease of implementation and lower cost ${ }^{27}$. Schemes with intermittent doses of $15 \mathrm{mg} \mathrm{Sb}{ }^{5+}$ obtained greater adherence and effectiveness, when compared with continuous schemes ${ }^{2}$.

According to the World Health Organization (WHO) ${ }^{35}$, adherence may be defined as the degree of a person's acceptance of the recommendations of the practitioner or other health care providers, which include taking drugs, following a diet, behavioral changes and attending appointments previously made. However, since it demands the participation of the patient, a good patient - health provider relationship should be established ${ }^{24}$.

The methods adopted to assess adherence to treatment may be classified as direct or indirect methods, but no method is considered the gold standard for this evaluation ${ }^{6}$. The direct methods quantify the drug or the metabolite in biological fluids and/or test specimens ${ }^{11,33}$. The indirect methods assess adherence through interviews with patients and counting the drugs that the patient still has remaining, which tends to be a method more prone to error caused by the patient ${ }^{11,33}$.

(1) Instituto de Pesquisas Evandro Chagas, IPEC/FIOCRUZ, Rio de Janeiro. RJ, Brazil.

(2) Universidade Federal do Rio de Janeiro, UFRJ, Rio de Janeiro, RJ, Brazil.

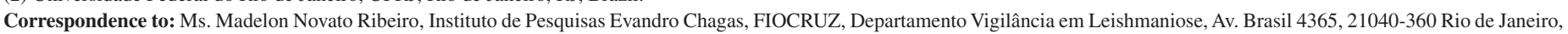
RJ, Brasil. Phone: 55.21.3865-2121. E-mail: mjrfarmacia@yahoo.com.br, nutballet@hotmail 


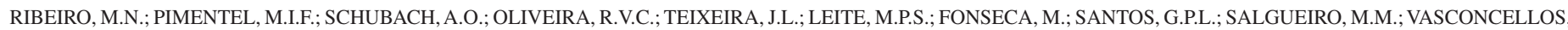
E.C.F.; LYRA, M.R.; SAHEKI, M.N. \& VALETE-ROSALINO, C.M. - Factors associated to adherence to different treatment schemes with meglumine antimoniate in a clinical trial for cutaneous leishmaniasis. Rev. Inst. Med. Trop. Sao Paulo, 56(4): 291-6, 2014

Adherence to therapy is a phenomenon subject to many factors that directly affect the patient ${ }^{24,31}$. Adherence questionnaires are methods used to assess results. The structured interview is one of the most used methods, because of its low cost and accessible implementation ${ }^{24}$. Some forms used in adherence interviews are found in literature, such as the Morisky test ${ }^{19,20}$

The $\mathrm{WHO}^{35}$ mentions several factors that can influence adherence to therapy: socioeconomic and cultural factors, those related to health providers and services, factors in relation to treatment and the patient.

The objective of the present study is to assess factors associated with adherence to patients included in a clinical trial with MA, in the treatment of cutaneous leishmaniasis in the state of Rio de Janeiro (RJ).

\section{METHODS}

Between 2008 and 2011, 60 patients with CL were observed. They were all over 13 years, participants in a controlled clinical trial, blind and in phase III of equivalence between the standard treatment scheme (20 $\mathrm{mg} \mathrm{Sb}^{5+} / \mathrm{kg} /$ day for 20 consecutive days) and other MA alternative schemes, ongoing at the Evandro Chagas Research Institute - IPEC, Oswaldo Cruz Foundation, Rio de Janeiro. The test was registered at the site http://clinicaltrials.gov - Identifier: NCT01301924, and approved by the Ethics Committee on Research/IPEC under the number 0055.0.0009.000-07.

Initially, sixty individuals were randomly distributed, 15 in each of the treatment groups by intramuscular administration of MA. From the initial $60 \mathrm{CL}$ patients, three were excluded, because they did not make the adherence evaluation: two of them refused to participate in the adherence evaluation, and the other one died. The 57 remaining patients were allocated as follows: $20 \mathrm{mg} \mathrm{Sb}{ }^{5+} / \mathrm{kg} /$ day for 20 consecutive days ( $\mathrm{n}=$ 13), $20 \mathrm{mg} \mathrm{Sb}^{5+} / \mathrm{kg} /$ day in two intermittent series of 10 days interspersed by a 10-day interval $(\mathrm{n}=14), 5 \mathrm{mg} \mathrm{Sb}{ }^{5+} / \mathrm{kg} /$ day for 30 consecutive days $(\mathrm{n}=15)$ and $5 \mathrm{mg} \mathrm{Sb}^{5+} / \mathrm{kg} /$ day in three intermittent series interspersed by 10 -day intervals $(n=15)$. For analysis purposes, the patients were grouped in high (20 $\mathrm{mg} \mathrm{Sb}^{5+} / \mathrm{kg} /$ day) and low ( $5 \mathrm{mg} \mathrm{Sb}^{5+} / \mathrm{kg} /$ day) doses; and consecutive and intermittent doses.

At the time of medicine administration, the patients were interviewed with the aid of a standardized questionnaire for socioeconomic data collection (gender, age, coming from an endemic area or not, people co-habiting in the same house, people sleeping in the same room, marital condition, level of education, personal and family monthly income, smoking habits, alcohol and drug consumption, who administers the medicine and their instruction level, whether the medicine affects the daily life) and assessment of satisfaction with treatment, IPEC and the healthcare team.

Clinical healing was defined as lesion scarring with no recurrence within a year after treatment. Monitoring abandonment was defined as the patient not returning to the appointments provided during the first year after the beginning of the treatment.

Adherence to therapy was evaluated according to four criteria (counting of vial surplus, monitoring card, Morisky test and modified Morisky test).
Counting of vial surplus: The vials for the treatment were supplied with a small surplus, and the patient was advised to return the vials that were not used at the next appointment. Patients were considered adherent when they delivered vials in equal or lower number than expected and non-adherent when they delivered a greater number of vials.

Monitoring card: Patients registered date and time of each dose in the monitoring card and requested the signature of the person who applied it. The patients that returned the card completely filled out, with intervals between doses not greater than three days, were considered adherent.

Morisky test: it was applied at the end of the treatment and comprised four dichotomous questions (each negative answer received one point); and a patient was considered adherent if they got four points and nonadherent when they got any other lower value ${ }^{19,20}$. The four questions of the Morisky test are: 1 - Have you ever forgotten to take your medicine? 2 - Sometimes do you forget to take your medicine? 3 - When you feel better, do you sometimes stop taking your medicine? 4 - At times, if you feel worse when you take your medicine, do you stop taking them?

Modified Morisky test: in the modified version, the $2^{\text {nd }}$ question regarding the schedule of taking the medicine was not considered, and a patient was considered adherent when they got three points and nonadherent, any lower value.

In the exploratory analysis, the simple frequencies of the qualitative variables and the median with interquartile range of the quantitative variables were calculated. The association of adherence (vial counting, Morisky test, modified Morisky test and monitoring card) with the sociodemographic and clinical variables and the treatment groups (high doses $20 \mathrm{mg} \mathrm{Sb}^{5+} / \mathrm{kg} /$ day - or low - $5 \mathrm{mg} \mathrm{Sb}{ }^{5+} / \mathrm{kg} /$ day; consecutive or intermittent doses) was evaluated by the Fisher's exact test. The Mann-Whitney test was used to assess the distribution difference of the quantitative variables in relation to the adherence variable.

The degree of concordance between the methods of adherence determination was evaluated by the simple Kappa index and categorized according to LANDIS \& $\mathrm{KOCH}^{12}$ as $\kappa:<0$ (non concordance), $\kappa: 0-0.19$ (poor concordance), $\kappa: 0.20-0.39$ (fair concordance), $\kappa: 0.40-0.59$ (moderate concordance), $\kappa:$ 0.60-0.79 (substantial concordance), $\kappa:$ 0.80-1.00 (perfect concordance). The adopted level of significance for all the statistical tests was 5\%. The Statistical Package for the Social Sciences (SPSS) version 16.0 was used for data analysis.

\section{RESULTS}

The median age was 40 years (minimum of 15 and maximum of 71), predominantly men $(68.4 \%)$, white $(61.4 \%)$, single or widowed $(54.4 \%)$, education to $1^{\text {st }}$ grade school $(57.9 \%)$, monthly family income between one and five minimum wages (each minimum wage corresponding to US\$ $321.77)^{3}$ and resident in RJ endemic areas (86\%). There was a median of three family members, ranging from one to eight members, with a median of two people sleeping in the same room (minimum one and maximum six). Regarding habits, it was found that the patients were $84.1 \%$ nonsmokers, 93.0 non-users of illicit drugs and $57.9 \%$ non-users of alcohol.

MA administration was done by health care providers in $71.9 \%$ of the cases, $68.4 \%$ of them with a college degree. The distance between 


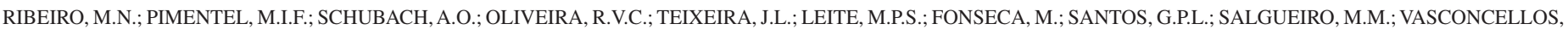

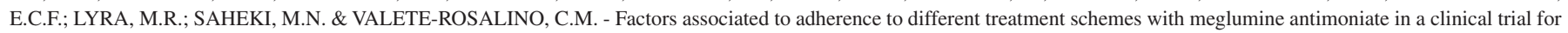
cutaneous leishmaniasis. Rev. Inst. Med. Trop. Sao Paulo, 56(4): 291-6, 2014.

Table 1

Comparison between adherence to high dose ( $20 \mathrm{mg} \mathrm{Sb} b^{5+} / \mathrm{kg} /$ day $)$ and low dose $(5 \mathrm{mg} \mathrm{Sb} / \mathrm{kg} /$ day $)$ schemes; and consecutive or intermittent administration

\begin{tabular}{|c|c|c|c|c|c|c|c|c|c|c|}
\hline \multirow{3}{*}{ Adherence } & \multicolumn{5}{|c|}{ Dose } & \multicolumn{5}{|c|}{ Type of administration } \\
\hline & \multicolumn{2}{|c|}{$20 \mathrm{mg} \mathrm{Sb}^{5+} / \mathrm{kg} /$ day } & \multicolumn{2}{|c|}{$5 \mathrm{mg} \mathrm{Sb}^{5+} / \mathrm{kg} /$ day } & \multirow{2}{*}{$p$} & \multicolumn{2}{|c|}{ Consecutive } & \multicolumn{2}{|c|}{ Intermittent } & \multirow{2}{*}{$p$} \\
\hline & $\mathrm{n}$ & $\%$ & $\mathrm{n}$ & $\%$ & & $\mathrm{n}$ & $\%$ & $\mathrm{n}$ & $\%$ & \\
\hline Surplus vial Counting & 20 & 74.1 & 26 & 90 & 0.171 & 22 & 78.6 & 24 & 86 & 0.485 \\
\hline Morisky test & 17 & 63 & 21 & 70 & 0.574 & 18 & 64.3 & 20 & 69 & 0.708 \\
\hline Modified Morisky test & 20 & 74.1 & 29 & 97 & 0.021 & 24 & 85.7 & 25 & 86 & 1.000 \\
\hline Monitoring Card & 23 & 85.2 & 26 & 87 & 1.000 & 23 & 82.1 & 26 & 90 & 0.470 \\
\hline
\end{tabular}

$\mathrm{n}=$ number of patients adherent to treatment. $p=p$-value. In bold, $p$-significant value.

Table 2

Assessment of the distribution difference of the quantitative variables, in relation to the adherence variable by the Mann-Whitney test

\begin{tabular}{|c|c|c|c|c|c|c|c|}
\hline \multirow{3}{*}{ Adherence methods } & \multicolumn{7}{|c|}{ Family members sleeping in the same room } \\
\hline & \multicolumn{3}{|c|}{ Adherence } & \multicolumn{3}{|c|}{ Non-adherence } & \multirow{2}{*}{$p$-value } \\
\hline & Median & Minimum & Maximum & Median & Minimum & Maximum & \\
\hline Surplus vial counting & 2.00 & 1 & 4 & 3.00 & 2 & 6 & 0.001 \\
\hline Morisky test & 2.00 & 1 & 4 & 2.00 & 1 & 6 & 0.037 \\
\hline Modified Morisky test & 2.00 & 1 & 4 & 3.00 & 2 & 6 & 0.001 \\
\hline Monitoring card & 2.00 & 1 & 6 & 2.50 & 2 & 4 & 0.012 \\
\hline
\end{tabular}

home and the administration site was less than $10 \mathrm{~km}$ in $82.5 \%$ of cases, and $63.2 \%$ of the patients reported that the treatment did not affect their daily life.

All patients reported satisfaction with treatment, IPEC and the medical staff.

$88.2 \%$ of the patients were healed. We observed $82.1 \%$ adherence to treatment by controlling returned vials, $86.0 \%$ by the monitoring card, $66.7 \%$ through the Morisky test and $86.0 \%$ through the modified Morisky test.

There was a greater adherence of the group that received low doses when evaluated by the modified Morisky test $(p$-value $=0.021)$. The comparisons between adherence assessment methods and high and low dose schemes, and between consecutive and intermittent doses are shown in Table 1.

We did not observe a significant correlation between the qualitative variables and adherence to treatment. We observed that there were a significantly greater number of persons sleeping in the same room among those that did not adhere to treatment, by the four adherence evaluation methods (Table 2). No significant correlation was observed between adherence to treatment and the other quantitative variables assessed: age and number of family members (Table 2 ).

The degree of concordance among the adherence evaluation criteria measured by the Kappa index was considered satisfactory (substantial and perfect concordance), for most criteria, except between the Morisky test
Table 3

Concordance among adherence to treatment assessment methods in each treatment scheme in the clinical trial

\begin{tabular}{lcc}
\hline Adherence & $\begin{array}{c}\text { Kappa } \\
\text { Index }(\kappa)\end{array}$ & $\begin{array}{c}\text { Degree of } \\
\text { Concordance* }\end{array}$ \\
\hline $\begin{array}{l}\text { Surplus vial counting and } \\
\text { Monitoring card }\end{array}$ & 0.736 & $\begin{array}{c}\text { Substantial } \\
\text { Concordance }\end{array}$ \\
\hline $\begin{array}{l}\text { Surplus vial counting and } \\
\text { Modified Morisky test }\end{array}$ & 0.736 & $\begin{array}{c}\text { Substantial } \\
\text { Concordance }\end{array}$ \\
\hline $\begin{array}{l}\text { Modified Morisky test and } \\
\text { Monitoring card }\end{array}$ & 0.418 & $\begin{array}{c}\text { Moderate } \\
\text { Concordance }\end{array}$ \\
\hline $\begin{array}{l}\text { Surplus vial counting and } \\
\text { Morisky test }\end{array}$ & 0.351 & Fair Concordance \\
\hline $\begin{array}{l}\text { Morisky test and } \\
\text { Monitoring card }\end{array}$ & 0.123 & Poor Concordance \\
\hline
\end{tabular}

Note: *Classification according to Landis JR, Kock GG. 1977.

and the monitoring card, which presented poor concordance (Table 3).

\section{DISCUSSION}

Factors associated with adherence of patients to different treatment schemes were evaluated during a clinical trial for CL treatment with MA, using a socioeconomic and evaluation of satisfaction with treatment questionnaire, return of non-used medicine vials, monitoring card, Morisky test and modified Morisky test. We did not find similar studies 


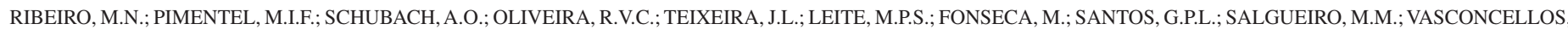
E.C.F.; LYRA, M.R.; SAHEKI, M.N. \& VALETE-ROSALINO, C.M. - Factors associated to adherence to different treatment schemes with meglumine antimoniate in a clinical trial for cutaneous leishmaniasis. Rev. Inst. Med. Trop. Sao Paulo, 56(4): 291-6, 2014

in literature, comparing adherence to CL treatment with MA measured using different assessment methods.

Similar to our results, the variable gender has not shown, in the literature, a significant relationship with adherence to therapy ${ }^{33}$. Regarding the socioeconomic factors, the correlation found between adherence assessed by all the methods studied and a higher number of family members sleeping in the same room may be related to a more precarious economic condition of the patients. The correlation between adherence and socioeconomic characteristics of the patients has been widely studied in other infectious diseases, and contradictory results that may vary with the methods used have been found ${ }^{5,15,25}$.

Although the use of medication did not alter the daily life of most patients, this occurred in $40 \%$ of them, which is understandable, considering that it is a parental medication that needs a qualified health professional to administer it, forcing the patient to leave home daily. It has been reported that patients present higher adherence levels to treatments when the administration is simple and the recommendations are easy to understand, they are short-term treatments and the patients do not significantly alter their daily lives ${ }^{7}$. On the other hand, adherence studies through intravenous (IV) administration of MA would require hospitalization or a day-hospital base, a condition that we cannot afford for all CL patients in Rio de Janeiro. We could, however, assume that adherence to treatment would be higher with IV MA, due to the discomfort associated with the use of intramuscular medication, and to the hospitalization itself ${ }^{21,27}$.

The high adherence level observed in the present study can be partially explained by the voluntary participation in the clinical trial and the good relationship between patient and health care providers at IPEC, as proved in the assessment questionnaire of satisfaction with care and the hospital. The good relationship between health care providers and patients is increasingly recognized as a determinant for adherence to therapy ${ }^{16,24}$.

A study of cultural and socioeconomic conditions showed that, despite the lower education and income of the population treated for ATL, the abandonment percentage was lower (1.6\%), when compared to percentages previously reported for the Metropolitan Region of Belo Horizonte $(25 \%)^{25}$. This result is compliant with the good adherence results of the present study, where the good relationship between patients and the health care team, as well as the voluntary participation, helped to obtain it.

Higher abandonment frequency in patients with a continuous treatment scheme, when compared to intermittent schemes of MA, has already been described ${ }^{2}$. Although our study did not present correlation between adherence and intermittent or continuous schemes, a significantly higher adherence was observed in the group that received low doses, when compared to the group that received high doses, when assessed by the modified Morisky test. The patients who received low doses may have presented better adherence, because the administration was simpler, there were fewer side effects and consequently lower modification of the daily life ${ }^{7}$. Especially for the elderly, the use of lower doses is recommended since the toxic effects of antimony are less pronounced and, consequently, the adhesion to therapy is greater ${ }^{23}$. Besides, it can be assumed that the refusal of two patients to respond to adherence assessment methods suggests that poor adherence is associated with a high dose.

It is believed that it is possible to monitor adherence to the prescribed treatment by counting the medication, as previously described in tuberculosis ${ }^{15}$. The medicine vial counting allows determination of the number of vials used, however, it is a method that requires collaboration and is subject to manipulation by the patient. It may also overestimate adherence, because the fact of returning the correct number of surplus vials, or less, does not necessarily ensure that the medication was correctly administered by the patient.

The monitoring card is a method that tends to underestimate adherence, because it needs the collaboration of the patient and the administrator: if, for some reason, it does not contain the signature of the administrator or if it is not completely filled out, the patient is considered non-adherent, even if they received the correct medication.

The Morisky test ${ }^{19,20}$ tends to overestimate non-adherence, as opposed to what is expected from indirect methods and does not give the patient the opportunity to express their difficulties and understand the treatment ${ }^{13}$. In the Morisky test, carelessness regarding medication time has been the answer most frequently given by the patients. Being a deposit drug, in which the therapeutic effect of antimony seems to be supplied by the fraction accumulated in the tissues $s^{4,8,17,26,32}$ carelessness, regarding the time when the medication is taken, it would not significantly affect adherence, if the daily administrations followed the schedule prescribed for the patient. When the modified Morisky test was applied, a significant correlation between adherence and low dose of meglumine antimoniate was obtained.

A study using the Morisky test showed low adherence level in leprosy treatment, indicating that patients did not have adequate knowledge of the principles of multidrug therapy, despite claiming to be familiar with leprosy and its therapy ${ }^{14}$. The Morisky test helps to identify the main reasons why patients do not adhere properly to treatment, which can help health care providers to find efficient solutions to solve adherence problems.

A study that assessed adherence to tuberculosis treatment by providing medication kits and the monitoring card revealed that counting the daily kits allowed assessing adherence to treatment ${ }^{15}$. In the present study, among the various methods, there was greater concordance between the vial counting and the monitoring card, although the first overestimates and the second underestimates adherence to treatment. When we applied the modified Morisky test, we observed a substantial concordance with the method of vial return and moderate with the monitoring card, thus suggesting that the first was adequate and simple to assess adherence of this group of patients.

We found a correlation between non-adherence to CL treatment with MA, assessed by various methods, and a higher number of family members sleeping in the same room. The assessment by the modified Morisky test showed better adherence in the group that received low doses of MA, than in the group that received high doses. Due to the good performance and simplicity of the method, when compared to other tests, we suggest the use of the modified Morisky test to assess adherence to CL treatment with MA. 


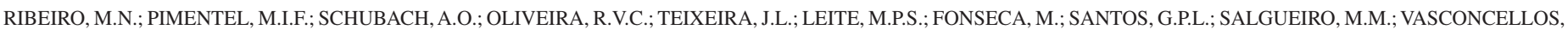

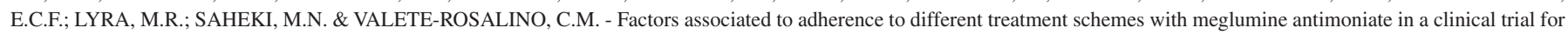
cutaneous leishmaniasis. Rev. Inst. Med. Trop. Sao Paulo, 56(4): 291-6, 2014.

\section{RESUMO}

\section{Fatores associados à adesão a diferentes esquemas de tratamento com antimoniato de meglumina em ensaio clínico para leishmaniose cutânea}

O desfecho favorável ao tratamento de uma enfermidade é influenciado pela adesão à terapia. Objetivamos avaliar fatores associados à adesão ao tratamento dos pacientes incluídos em ensaio clínico de equivalência entre o esquema de tratamento padrão e alternativos com antimoniato de meglumina (AM) no tratamento da leishmaniose cutânea (LC) no estado do Rio de Janeiro. Entre 2008 e 2011, 57 pacientes com LC foram entrevistados através de questionário para coleta de dados socioeconômicos. Para monitorização da adesão foram utilizados os seguintes métodos: contagem de ampolas excedentes, cartão de acompanhamento, teste de Morisky e teste de Morisky modificado (sem a pergunta referente ao horário). Observou-se adesão de $82,1 \%$ (devolução de ampolas), 86,0\% (cartão de acompanhamento), 66,7\% (teste de Morisky) e 86,0\% (teste de Morisky modificado). Houve forte concordância entre o método contagem de ampolas e cartão de acompanhamento, bem como teste de Morisky modificado. Verificou-se associação significativa entre maior adesão ao tratamento e baixa dose de AM, bem como com menor número de pessoas dormindo no mesmo quarto. Recomendamos a utilização do teste de Morisky modificado na avaliação da adesão ao tratamento da LC com AM por ser método simples e com bom desempenho quando comparado aos outros testes.

\section{ACKNOWLEDGEMENTS}

Cláudia Maria Valete-Rosalino, Armando de Oliveira Schubach and Madson Pedro da Silva Leite were responsible for the design of the study. Madelon Novato Ribeiro, José Liporage Teixeira and Monique Reis da Fonseca collected data. All authors were responsible for conducting the study and managing data; Madelon Novato Ribeiro, Cláudia Maria Valete-Rosalino, Raquel de Vasconcellos Carvalhaes de Oliveira, Maria Inês Fernandes Pimentel and Armando de Oliveira Schubach analyzed and interpreted data, and prepared manuscript; all authors reviewed and approved manuscript.

We are grateful to Jacline Novato Ribeiro, Margareth de Araújo Silva, Michele Aparecida Ferreira Moreira de Oliveira, Fátima Peres Lima Dantas and Felipe Maia Maquieira da Silva for their help with the patients before the interviews. We also thank Dr. Sandro Javier BedoyaPacheco for help with the database.

This study was funded by PAPES-FIOCRUZ, National Council for Scientific and Technological Development (CNPq) and Carlos Chagas Filho Foundation for Research Support in the State of Rio de Janeiro (FAPERJ). Funding agencies had no interference in the design and conduct of the study; collection, management, analysis and interpretation of the data; and preparation, review, or approval of the manuscript.

\section{REFERENCES}

1. Ashford RW. The leishmaniasis as emerging and reemerging zoonoses. Int J Parasitol. 2000;30:1269-81.
2. Azeredo-Coutinho RB, Mendonca SC. An intermittent schedule is better than continuous regimen of antimonial therapy for cutaneous leishmaniasis in the municipality of Rio de Janeiro, Brazil. Rev Soc Bras Med Trop. 2002;35:477-81.

3. Brazilian Central Bank. Currency conversion. [cited 2012 January 01]. Available from: http://www4.bcb.gov.br/pec/conversao/conversao.asp

4. Chulay JD, Fleckenstein L, Smith DH. Pharmacokinetics of antimony during treatmen of visceral leishmaniasis with sodium stibogluconate or meglumine antimoniate. Trans R Soc Trop Med Hyg. 1988;82:69-72.

5. Conrad P. The meaning of medication: another look at compliance. Soc Sci Med 1985;20:29-37.

6. Cramer JA, Mattson RH, Prevey ML, Scheyer RD, Ouellette VL. How often is medication taken as prescribed? A novel assessment techinique. JAMA. $1989 ; 261: 3273-7$

7. Goldberg AL, Cohen G, Rubin AH. Physician assessments of patient compliance with medical treatment. Soc Sci Med. 1998;47:1873-6.

8. Goodwin LG, Page JE. A study of the excretion of organic antimonials using a polarographic procedure. Biochem J. 1943;37:198-209.

9. Goodwin LG. Pentostam (sodium stibogluconate): a 50-year personal reminiscence. Trans R Soc Trop Med Hyg. 1995;89:339-41.

10. Herwaldt BL. Leishmaniasis. Lancet. 1999;354(9185):1191-9.

11. Haynes RB, Taylor DW, Sackett DL, editors. Compliance in health care. Baltimore: Johns Hopkins University Press; 1979

12. Landis JR, Kock GG. The measurement of observer agreement for categorical data Biometrics. 1977;33:159-74

13. Leite SN, Vasconcellos MPC. Adesão à terapêutica medicamentosa: elementos para a discussão de conceitos e pressupostos adotados na literatura. Cienc Saúde Colet. 2003;8:775-82

14. Lira KB, Leite JJG, Maia DCBSC, Freitas RMF, Feijão AR. Knowledge of the patients regarding leprosy and adherence to treatment. Braz J Infect Dis. 2012;16:472-5.

15. Maciel ELN, Silva AP, Meireles W, Fiorotti K, Hadad DJ, Dietze R. Tratamento supervisionado em pacientes portadores de tuberculose utilizando supervisores domiciliares em Vitória, Brasil. J Bras Pneumol. 2008;34:506-13.

16. Marinker M, Shaw J. Not to be taken as directed: putting concordance for taking medicines into practice. BMJ. 2003;326:348-9.

17. Miekeley N, Mortari SR, Schubach AO. Monitoring of total antimony and it species by ICP-MS and on-line ion chromatography in biological samples from patients treated for leishmaniasis. Anal Bioanal Chem. 2002;372:495-502.

18. Ministerio da Saude. Secretaria de Vigilancia em Saude. Manual de vigilancia da Leishmaniose Tegumentar Americana. 2. ed. atual. Brasilia: Ministerio da Saúde; 2010

19. Morisky DE, Levine DM, Green LW, Smith CR. Health education program effects on the management of hypertension in the elderly. Arch Int Med. 1982:142:1835-8

20. Morisky DE, Green LW, Levine DM. Concurrent and predictive validity of a selfreported measure of medication adherence. Med Care. 1986;24:67-74.

21. Oliveira-Neto MP, Schubach A, Mattos M, Gonçalves-Costa SC, Pirmez C. Treatment of American cutaneous leishmaniasis: a comparison between low dosage $(5 \mathrm{mg} / \mathrm{kg} /$ day) and high dosage (20 mg/kg/day) antimony regimens. Path Biol. 1997;45:496-9. 


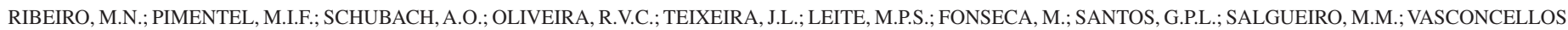
E.C.F.; LYRA, M.R.; SAHEKI, M.N. \& VALETE-ROSALINO, C.M. - Factors associated to adherence to different treatment schemes with meglumine antimoniate in a clinical trial for cutaneous leishmaniasis. Rev. Inst. Med. Trop. Sao Paulo, 56(4): 291-6, 2014

22. Oliveira-Neto MP, Schubach A, Mattos M, da Costa SC, Pirmez C. Intralesional therapy of American cutaneous leishmaniasis with pentavalent antimony in Rio de Janeiro, Brazil - an area of Leishmania (V.) braziliensis transmission. Int J Dermatol. 1997A;36:463-8.

23. Oliveira-Neto MP, Mattos M, Pirmez C, Fernandes O, Gonçalves-Costa SC, Souza CFS, et al. Mucosal leishmaniasis ("espundia") responsive to low dose of N-methyl glucamine (Glucantime (®) in Rio de Janeiro, Brazil. Rev Inst Med Trop Sao Paulo. 2000;42:321-5

24. Osterberg L, Blaschke T. Adherence to medication. N Engl J Med. 2005;353:487-97.

25. Passos VMA, Barreto SM, Romanha AJ, Krettli AU, Volpini AC, Gontijo CM, et al. Leishmaniose tegumentar na região metropolitana de Belo Horizonte: aspectos clínicos, laboratoriais, terapêuticos e evolutivos (1989-1995). Rev Soc Bras Med Trop. 2001;34:5-12

26. Roberts WL, Berman JD, Rainey PM. In vitro antileishmanial properties of tri- and pentavalent antimonial preparations. Antimicrob Agents Chemother. 1995;39:1234-9.

27. Schubach AO, Marzochi KBF, Moreira JS, Schubach TM, Araujo ML, Vale AC, et al. Restrospective study of 151 patients with cutaneous leishmaniasis treated with meglumine antimoniate. Rev Soc Bras Med Trop. 2005;38:213-7.

28. Shaw JJ. Taxonomy of genus Leishmania: present and future trends and their implications. Mem Inst Oswaldo Cruz. 1994;89:471-8.

29. Valencia C, Arévalo J, Dujardin JC, Llanos-Cuentas A, Chappuis F, Zimic M. Prediction score for antimony treatment failure in patients with ulcerative leishmaniasis lesions. PLoS Negl Trop Dis. 2012;6:e1656. doi: 10.1371/journal. pntd.0001656. Epub 2012 Jun 12 .
30. Vasconcellos EFC, Schubach AO, Valete-Rosalino CM, Coutinho RS, ConceiçãoSilva F, Salgueiro MM, et al. American tegumentary leishmaniasis in older adults: 44 cases treated with an intermittent low-dose antimonial schedule in Rio de Janeiro, Brazil. J Am Geriatr Soc. 2010;58:614-6.

31. Vasconcellos EC, Pimentel MIF, Schubach AO, de Oliveira RV, Azeredo-Coutinho $\mathrm{RB}$, Silva FC, et al. Intralesional meglumine antimoniate for treatment of cutaneous leishmaniasis patients with contraindication to systemic therapy from Rio de Janeiro (2000 to 2006). Am J Trop Med Hyg. 2012;87:257-60

32. Váquez L, Scorza Dagert JV, Scorza JV, Vicuña-Fernández N, Petit de Peña Y, López $\mathrm{S}$, et al. Pharmacokinetics of experimental pentavalent antimony after intramuscular administration in adult volunteers. Curr Ther Res Clin Exp. 2006;67:193-203.

33. Vermeire E, Hearnshaw H, Van Royen P, Denekens J. Patient adherence to treatment: three decades of research. A comprehensive rewiew. J Clin Pharm Ther. 2001;26:33142 .

34. World Health Organization. Letter to Aventis pharma drug regulatory affairs, Europe. Essential drugs and medicines policy. Geneva: WHO; 2001.

35. World Health Organization. Adherence to long-term therapies: evidence for action Geneva: WHO; 2003

Received: 22 July 2013

Accepted: 10 January 2014 